\title{
OPERATIING MAIUUAL
}

\section{FOR CONDUCTING A IOCAI MOD IRNIZING CAMPAIGN}

(Prepared by the Advisory Committes on Reconditioning, Remodeling, "and hodernining, Division of Buildjng and Housing.)

\section{CONTENTS}

Introductio

Organization chart $\ldots \ldots \ldots \ldots \ldots \ldots \ldots \ldots \ldots \ldots \ldots \ldots$

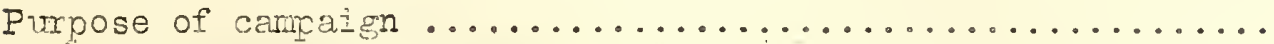

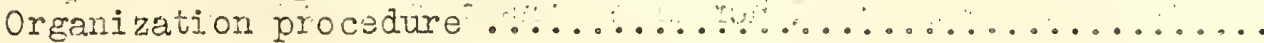

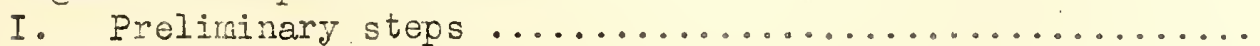

II. Plan of action

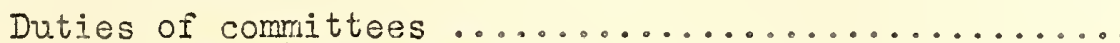

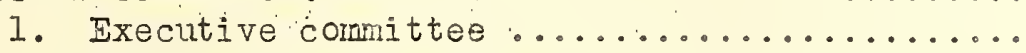

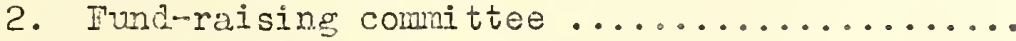

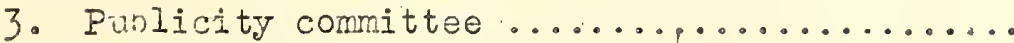

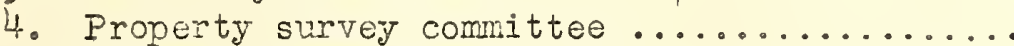

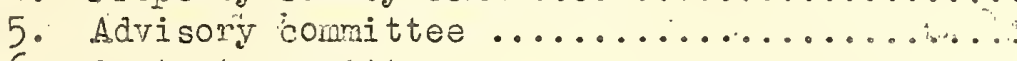

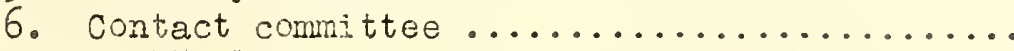

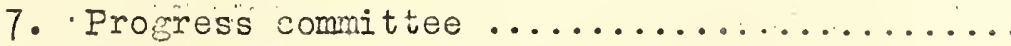

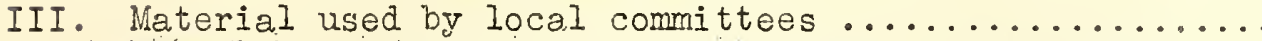

Example 1. Card used in "Create Emoloyment" appeal....

Example 2. Card used by contractors and dealers ......

Example 3... Ietter sent by Property Survey Committee to home owners .................... 12

Exarnle 4. Service emblem for display purooses ...... 12

Example 5. Hone canvasser's manual - Instructions..... 14

Example 6. Check-list card left with home owner by

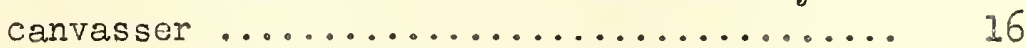

Example 7. Sugeestod jmprovements and repairs folder.. $\quad 17$

Example 8. Description of home nodernization and improvement demonstretion contest.........

Example 9. Radio address delivered in connection

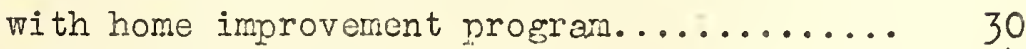

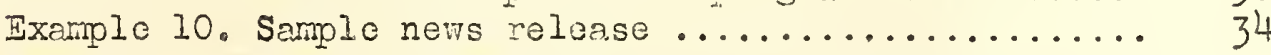

Example 11. Report showing business and omployment which resulted from local home-improvement

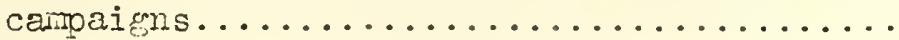




\section{INTIRODTCTION}

This nanual is intended to assist cities and towns to develop Working prograns with mjor objectives of (1) providing work to those directly and indirectly involved in the modernization and repairing of homes and other properties; (2) holning individual home omers and rental property omer's to keep up their property values by making neoded repairs and improvements during periods of provailing low costs; (3) in goneral to promoto comunity clean up and boautification activitios.

The information contained heroin is based on a careful study of successful hoic zodernizing carpaigns conducted botrecn January 1 and Decmbor 31 ; 1932, in sone 32 cities in the United States, Which rovorted exponditures by property omors of approxirately, 66 million dollars for lebor and natorials resuling directly from these comunity irprovonent activitios.

Moro detailed information will rlady be furnished to those interested, in so far as it is availoble, by the corittee on Reconditioning, Rozodeling, and Modurntzing of the Bureau of Standards, Departrient of Comierce. 
ORGAIVIZAIIOIN CEARE

PURPOST OF CAMPAIGN

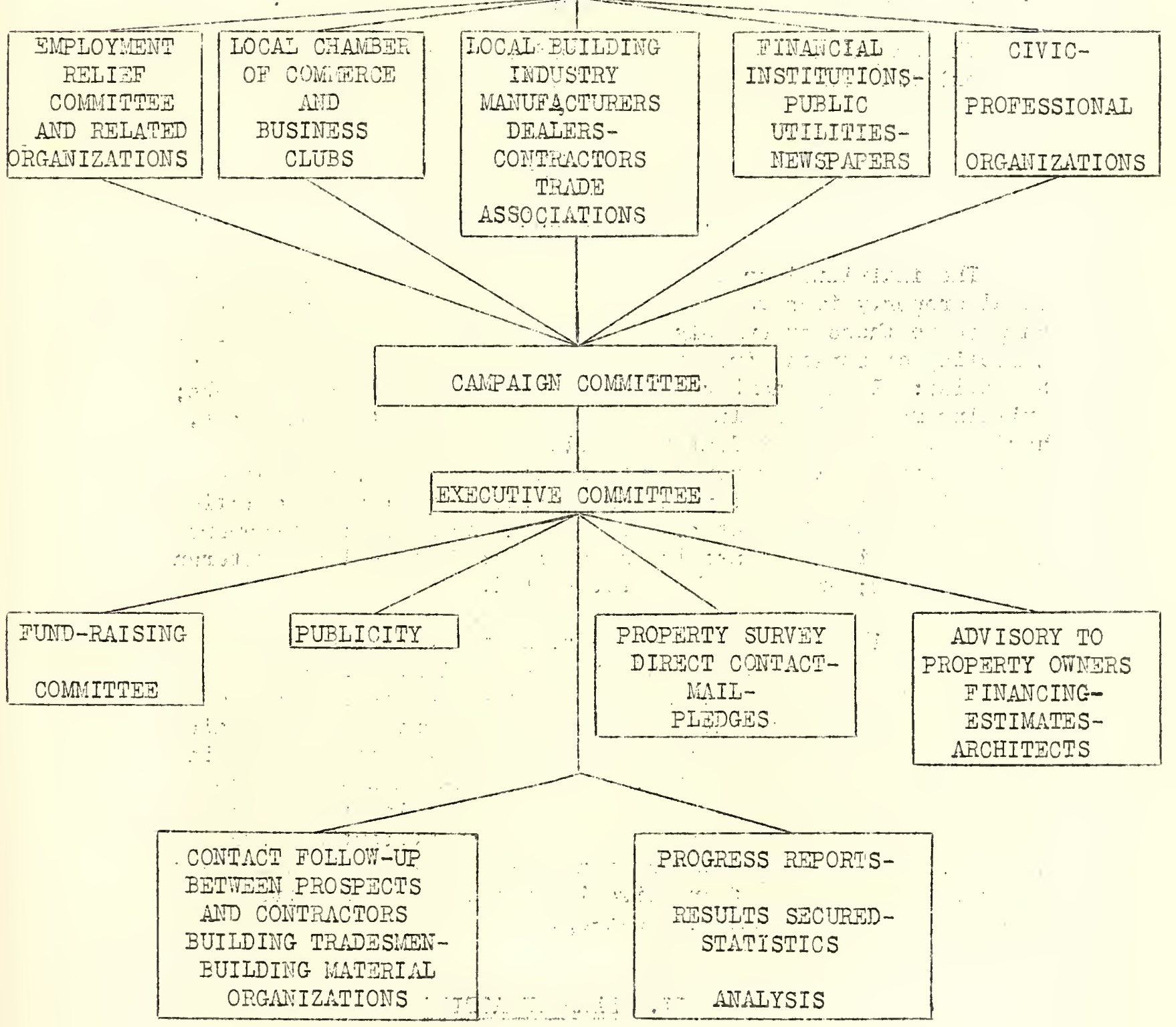




\section{PURPOSE OF CAIPAIGN}

]. To stimulate erployment and businoss.

2. To assist in waintainine proporty values by akin rooded irnorovenonts and repairs at prevailing low costs.

3. To encourace commity clean us and beautification.

The carpain or sanization should raintain active contact wi th oxisting culoymet rulier or rolated or ganizations.

\section{ORGAUIIZATIOIN PROCEDURE}

\section{PRIUININARY STEPS}

Tho indsvidual or or canization intercsted in initiating a local proporty irprovouent cespainn should briofly explain the purpose to those presuably interested, by letter or othervise. A neeting of persons from the following local frowes should then be called: Local charber of corrierce and other business clubs; building waterial and lubor dealors and wanufacturers; paint, hardware, and sinilar dealers; building contractors, subcontractors and labor representatives; architects; insurance and roal estate arents; banks and building and loan associations; local public utility interests; trade associations; newspapors and local radio stations; luncheon clubs; fraternal and veteran organizations; and any others interested.

If possible, a, terporary chairman and secretary should previously be selected to conduct this neeting. Several authoritative spealiers should be appointed to present the need of carrying on a civicuinded cormunity nodernizing and repair catipaign, and to furnish data on bonoficial results secured in other cities over the country. It should be errohasized that this proposed locel effort will be successful in tirect neasure to the arount of cooperation Eiven by the contributinf, organizations. The interest expressed at this reeting should largely deterrine the extent of organization which should be atterpted in establishing the carpaign set-up.

\section{PLAIT OF ACIION}

After this meeting, it should be relatively simple to choose a representative roup as members of the Eeneral canpaign corrittee, from which should be selected the oxecutive comittee, preferably from anong the leadine business or ganizations. The business group represented on the campaign 
comittee should bé asked to contribute a nominal sun to cover campaign expenditures, and the Furd-Raising Comittee should solicit

others not prescint.

(Notc: A study of twonty trpical citios whore succcssul imorovement campaigns have been conducted, where the population ranges from 10,000 to 300,000, shows campaisn expenditures varying from $\$ 100$ to $\$ 5,000$, aid an atrerage per capita expense of less than two certs producing an averase per capita investment in property improvements of $\$ 14$.)

\section{Duties of Cominitecs}

\section{Executive Committee}

This administrativo body of the campaimn shovld be responsible for carrying out all the details of the campain organization and particulariy to centralize the work of the verious other comittees so as to furish the necessary leadership of. the whole activity.

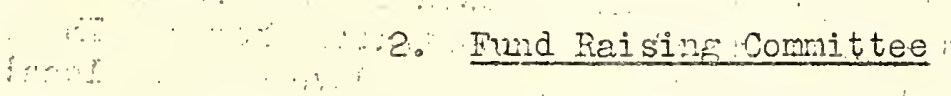

This committee should be composed preferably of representatives of the different groups active in the campain. It will determine the estimated budset required to carry on the local improvement drive and directly sponsor the solicitation of necessary furids, through correspondence and personal contact. Solicitation should include organizations materially beinefiting from the carpaisn, particularly local building material and lumber dealers and mamufacturers; contractors; merchants handing tools, home equipracnt, and remodelins materials; and other interested or gailzations. Every Dusiness organization should be welcomed as a contributor, recardless of its size. In some communities extra campaign funds have been raised through benefit amusement programs. Successful campaigns have been organized in various cities with individual contributions ranging from $\$ 5$ to $\$ 500$.

\section{Publicity Committee}

This comittee should include nembers trained in newspaper and probicity-work. It should stpervise the proparation of news stories, radio talks, and advertising copy on modernizing. for the local newspapors. Live news stories about the carpain activitio's should appear proninently and trequently in the papers. They should include news iteras reaarding owners who are modernizine thoir property and photographs showin: the prokiress of the rork. Placards or neat windon cards may be uscd at ali aodernizing jobs to stimulate public interest. Billboards, theator scroens, store window cards, and truck placards are other publicity mediuns used for sproading the novement. 
Sore comunitios have stirred local enthusiass through public mass neetings, float" parades featuring present low costs "of building materials and equipnent, and with huge themometers or dials prominently displayed.

Sarple proof sheets of newspapor advertising; window cmblens, suggested radio talks, statistical nows stories, and other publicity suggestions may be obtained from the Corrittee on Reconditioning, Rerodeling, and Modernizing. (Soe samles of taterial pages 11 to 35)

Public interest in the property irprovenent carpaign has also been developed in various corrutities by having caxaign speakers address Iuncheon and civic cormunity clubs; by urging, in the churches, the cooperation of tho public: and through conducting competitive essays in tho local junior and senior high schools. As expressed by. one carpaign organization: "Every possible rieans of reaching the public and creating a condition of house consclousness was utilized."

Effoctive public interest has been aroused in sorje localities through "before" and "aftor" modernized demonstration homes. These houses have been renodeled, from plans carefully developod by local architects, and then nade available for public inspection. A particularly interesting denonstration nay be held where it is possible to find two homes close together and practically identical, and both in need of irprovement. The improverients ray be completed in one house only and the other used as a "beforell illustration. Cooperation of the ownors in perritting such derionstrations can generally be secured by the conaittee through concessions made on costs of naterials for prospective work.

The comittce nay also use a hore inspection plan and notify home owners that free inspection service is availablo to thers, and that a writton roport, signod by the comittce, will be delivered to then after careful inspection has shown certain needed home inrovenents or repairs. "This service can well be managed through tho Advisory Cormittee, and in turn handled through represcntatives of building uaterial companies or contractors. They should be instructad, hovever, that this is a hor se service and not a direct sales approach.

When the inspection report is delivered to the homo owner, permission nay be secured fron hin to have a dealer's or contractor's representative call to offer cost infordation and other specific advico. These prospects should bo turined over to the Contact comittee for assignient to the proper business concerns. 


\section{Property Survey Comittee}

This comattee should include real estate men, building material and equipment dealers and manufacturers, leaders in past commity drives, and other members particularly familiar wi th home properties in the comunity. Carerul consideration should determine the best method of conducting an intensive house and small comercial property canvass . This property check-up hes been handled successfully in other cities by the following thods:

(a) Through mailing check cards, listing suggested repairs and improvements, from carpaign headquarters to a selected list of hore owners, briefly explaining the purpose of the campaign. The citizen is askod to check, sign, and mail the selfaddressed return card.............

(b) Asking obudents in public sçools to carry home check list cards, each with a tear card to be returned to campaign headquarters, through the shools.

(c). Makiñ a systenatic house-to-house canvass, using voluntary workers, equipped with parphlets listing sugrested repairs and improvernents and pledee cards to be signed by home owners. Commuities havo carricd out this city-vide home canvass by-..several means, exarples of which are as follows:

\section{Dividing the city, according to school or other:} districts, and making house-to-house calls through district assigned nembers of local women's clubs, veteran service organization merbers, junior: chamber of commerce mernber's, city employees, junior scouting organizations, neighborhood clubs, unemployed salesmen, office workers, and others available for this work.

When the group to make the house canvass has been chosen, the members should be rell posted on the purpose and aims of the canvass through advance and daily campadgn meetings conducted along the same general lines as other community drives. The effective organization of this group of voluntary canvassers, strongly imbued with a sense of civic responsibility, and intelligently familiar with the proper approach in urging home owners to make needed improvements, is of primary importance in assuring a successful campaing. The home improvement pledge cards; secured by the voluntary workers from how onners; should be turned over to the Executive Comittee for careful indexing and proper follow up by the contact Cormittee. 


\section{Advisory Cormittee}

This comittoo should include nembers fror local banis and building and loan associations, contractors and ásalers familiar with local costs of hone irspoverents and repairs, and architectural and enginecrirg socictios, or individual remresentatives who 11 furnish advice to prospects on proposed improvement plans. One of the important duties of this conittoe is to rork ont the best possible methol for raking extended payments possible to responsible owers for needed irprovenents "This has been accorististed in other coriunitios through loans rade by existing firancial institutions cooperating in the car aim; by establishirm sccial loan funds handled throu th interestod businoss or çanizations: and in some cases by material surriy dealers financine the jobs on a series of short-tern notes. In sone localitios comorations have instituted loan funds for horc improverents linited to their om cimloyees." In other cases contractors have inanced rork in their field. In solle of tho snaller comunjties a type of honor syster has been uscd successfully. One town set up an "Honor Ioan Organization," incorporated to cregace in home loans. Difforont persons interosted aerced to bo responsible to the corporation up to a certain arount... of money for the payment of 'any loans approved by the Honor Loan Comittec. No person was allowed to borrow over $\$ 200$.

In a nurber of comanitios these comitfees stronly emphasized to all the local financial institutions the desirability, from a business standpoint, of maline credit available for improvenents to responsible hore omers. It was also pointed out that, wherever possible, requosts for curtailment of nortrages should "rroporly be reconsidered by the bank when needed improvements, wich would add to the value and "desirable, risk" features of the pronerty, yiere intended.

This comittee should be prepared to offer sound advice to horic owners on proposed improverent plans, to assure that intended projects would be wiso economically as vell as increase farily conforts. In general, it should undertake to see that the movement as a whole is carried on with the rost scrurulous regard for the best interests of the hone omners, and to purd apainst individuals bejpg induced to fo aread with work of an extravagant or architecturaliy undesirable character.

This corrittec should also bo propared to turnish estinates of costs covcring proposcd ropairs or improverients, and it may preparo an ostimated price list, subscribed to by local contractors, covering a nurber of the hore comon home improvemonts. If such a list is used it should be available to the Survey Cormittee for goncral distribution. (Note: A Iist of 
Eovornent pulications of special interest to hono omnurs may be secured from the Conintieo or Roconditioning, Fornodeling, and Módernizing.)

\section{Coniact Comattue}

This committee, preferaty, should include memers resresentative of all the business ormanizations interested in the campaign. The responsibility of carefully. handling the pledge cards so as to protect home owners asainstindiscriminte solicitation, to distribute fairly requests for contractors, and yet to secure the laresest possible arount of cmlojment and business, rests on its shoulders.

In some communities this committee may sponsor a census of unemployed building tradesmon, making the lists that aro compiled availatile for the joos resulting fron the cempaign, through a local existing employment bureau or one set up by the Campaign Committee.

The home impovment pledre cards require careful indexing to divide them into their propur classifications. Somo owners request that a preferred contractor call; others ask for a qualified workman to make sonc small repair; and othors merely list needed improvenents and state that the representative of a material dealor or contractor may call on the owner to offer specific information and suksestions.

Each classification of cards will require prompt action by the Contact Comittee. In some comunities, these cards, listing needed improvements with peruission for the representative of a material or equipment dealer or contractor to call, may be assigned in rotation to contributing nombors in those lines of work, and a salcs ropresentative and contractor nay call on the owner tofether. Where perisission is not given by the property owner to have the representative of a business organization call, a follow up ray be diplonatically made by the corrattee to secure this permission, pointin out to the hore owner the fact that no obligation vill bo incurred, and that the injormation secured will be helpful for future planning even if no work is to be undertaken at once.

It is also the duty of the contact Comittee to erroshase to all the comintice mombers that while every offort is made to distribute equitably the reque t cards from hone owners for information, it is physically irpossible to assure each neraber an exact share of the prospectivo business. In ract, contractors and dealcrs who are not cooporating in the carmaign are practically cortain to benefit by it. Instead of letting such itcins receive undue attention, however, the point to stress to all concerned is that this is a civic improvenent prograr, which will, in addition to securing direct business 
and employment during the camping have a stron benefjoial influence in making citizens of the whole comunity conscious of the desirability of attending to needed repairs and improvements periodically and theroby securing thom as aovid prospects for continuous purchases of labor and matoriais.

\section{Propress Committee}

This committee, profembly, should include members exmerienced in business statistics. A ceratul "record shonld be kent of all matters portaining to the cempei showing wethods usod in the carpaign organization, and estimated results secured in terms of business and employment. Recomendations could also be ircludod in the roport for future reference, and guidance.

If it is practical to do so, it is desirablo to keec an estimated recórd of improvement and repair jobs classified as to kinds of jobs, materials, and equipment, in proportion to the work resulting: from the campaign. F'or example - in one of the lare mid-western cities such a record shows the following classification of naterials and trades emoloyed in its nodernizing canpaign, describing mori under wy, or under contract, between March 14 and April 23, 1932:

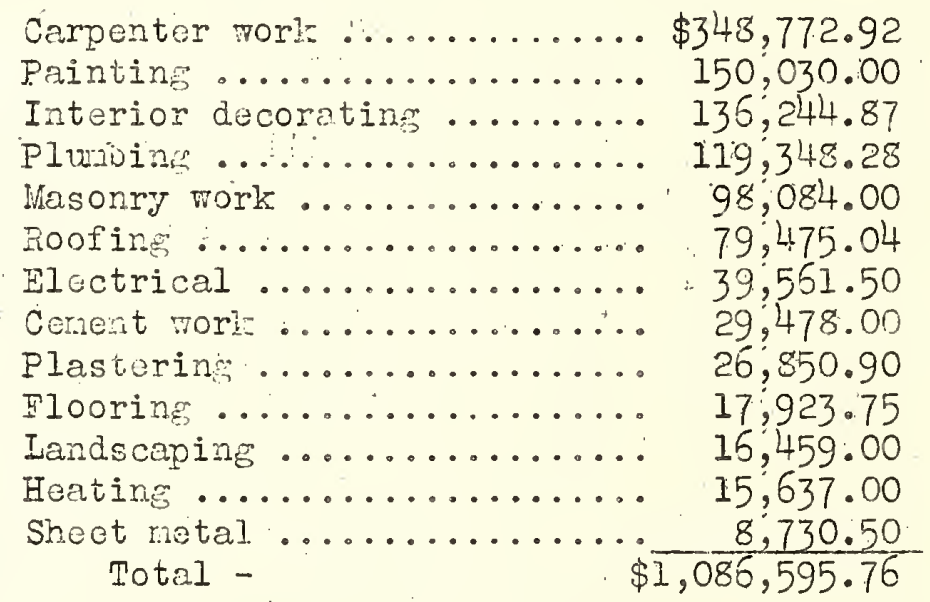

Such a report is particularly irportant as a mide for other communities interested in conductine similar activities. 


\section{MATERIAL USPD BY IOCAL COMMTREES}

The followine matarial represents samplos of publicity and pledge cards used in various commioy modorniuing campaigns:

Example 1. Self addressed card usci for ajsiribution throuec school students ana roturned to campaj.gn comittec through school. This campainn uscd the "Create Enolojment" appecl.

$$
\text { , Juİ } 2 E, 1932
$$

\section{Doar Fellow. Citizon:}

The Chamber of Comarce, in collaboration with other agoncies, is sponsoring a Buildinf Modimization Campaign. The pumpose of the drive is to create mork for unomployed building craftsmen throush a campan of publicity and advertising in an offort to get owners of homes ard othor property to ropair, romodel or modarnize such structures Now. 3uilain materials are at least $20 \%$ cheaper now than for hany years, oxparieuced and skilled buildinf artisans are plontiful, and they need the work. If exiven emoloymert now, it will reduce very considorobly the anount of money which the citizons of and pay out for rolief for the wermloyed in our city next winter.

Will rou, as a citizon of, and a civic boostor for our city, fill in the accomanyine card, and return it to tho solool throuh which this commication reachod vou.

In this way you will be aiding vary materially in tisis canpain, and your assistanco will be freaty appreciated.

$$
\text { Cordially yours, }
$$

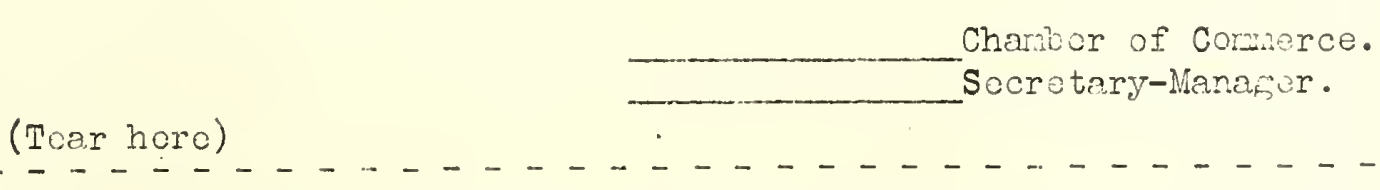

Do your om the hone in rhich you are not residina?

If not, Eivo naze of party or owmer frow thom you ront

What repairs, remoduline, or nodurnization is necossary in or on your. home to makc it modern?

If thore is any othor property, such as a garage, stable, shod, etc. on the promisos you occupy, wich noeds ropairs, tell what ropairs are noeded.

If you own any property, do you nood or went financial assistanco to ropair or ronodel it?

Date

Na:10

Adriress

ITaic of School

To bo réturned to school. throuh which it was roceivod for Chezior of Comiorce. 
Exaruple 2. Solf addrossed card us d by coutractors and dealors to report work undertaken by ho.ue onners. to loeal cempina headquarters. ( 4 by 6 in. card)

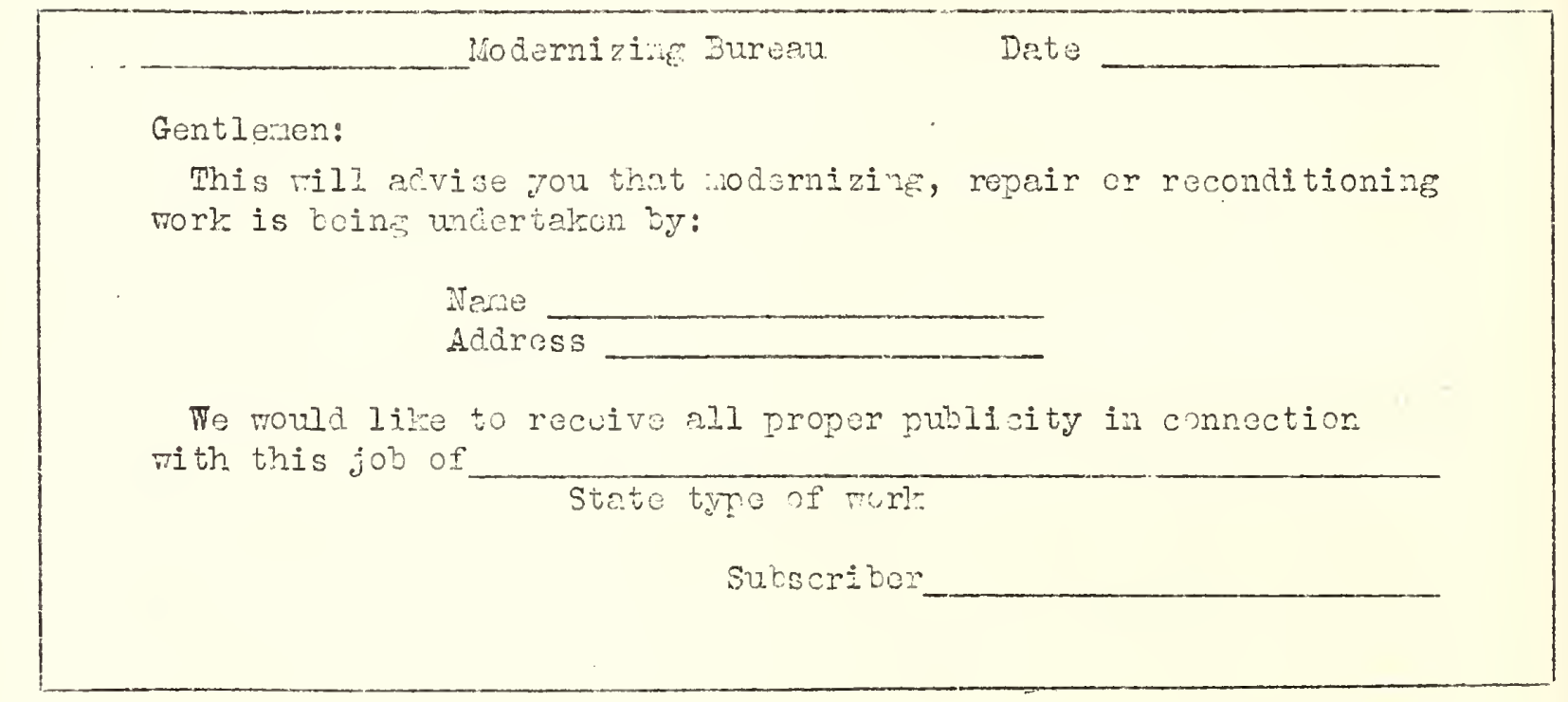

Exarzole 3. Letter sent by Froporty Surrey Comittee to home owners who are startin woris, as reported by contractors or dealers. A service star criblen or sutale placard for display during the carraien is also inclosed.

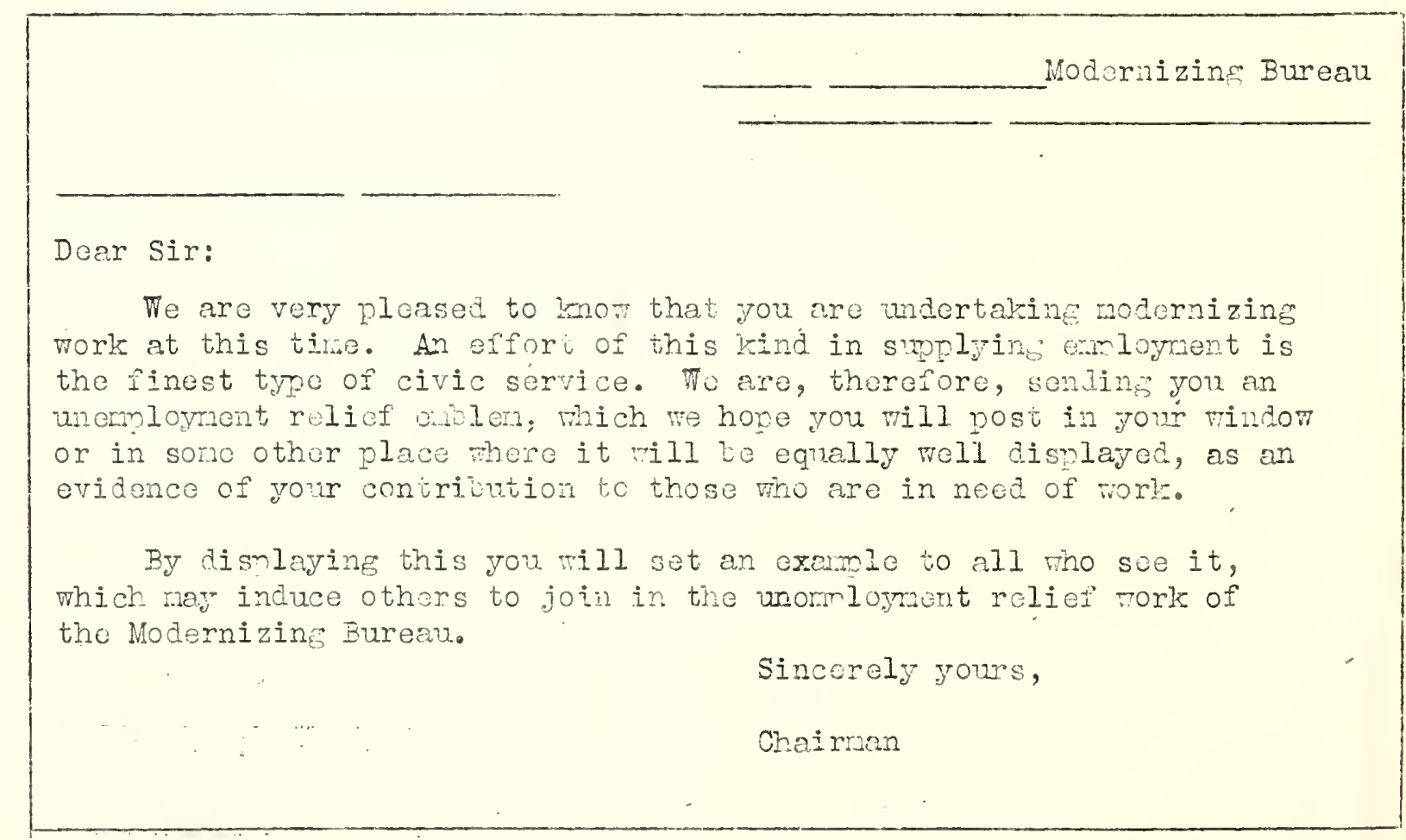

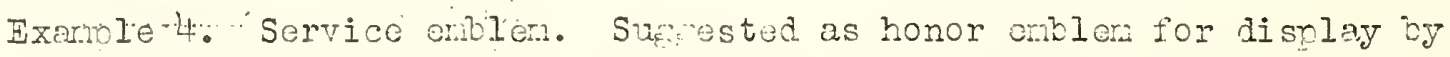
howe ownors, and also to to nrominently displajed in business places of organizations cooperating in tho camaign. (Sce noxt page) 


\section{MODERNIZE FOR}

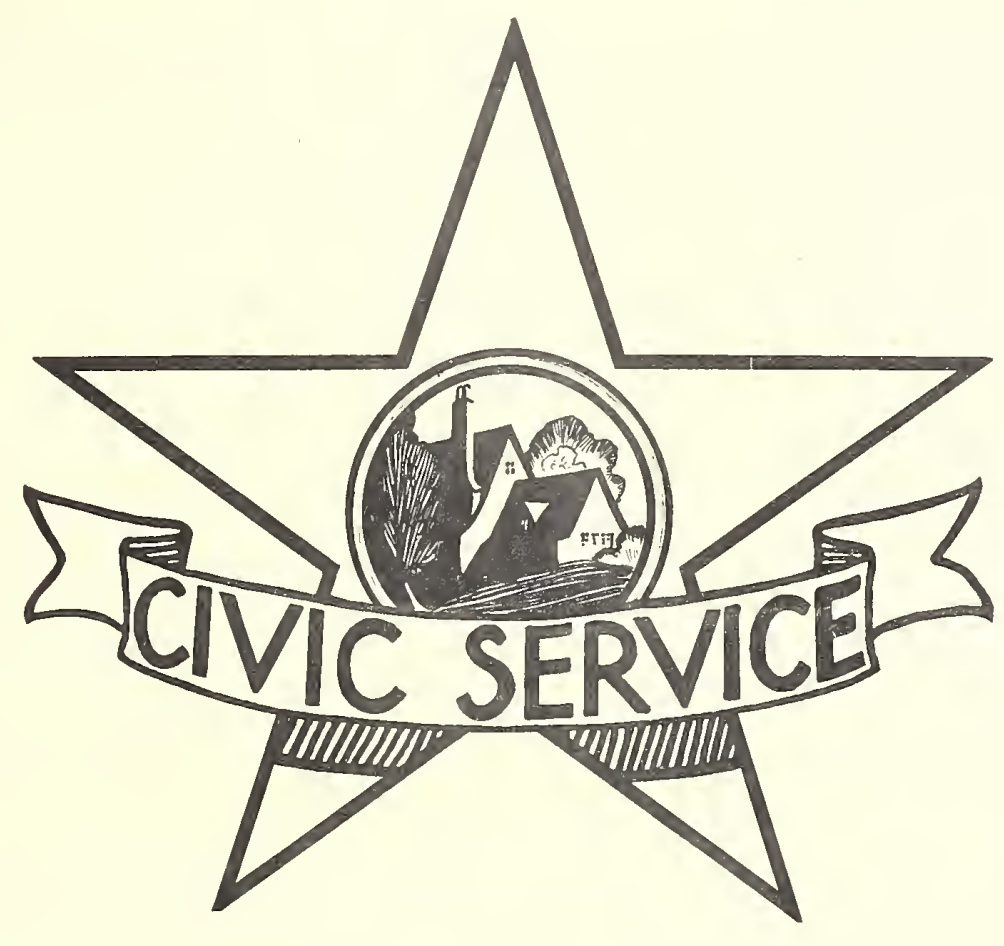

$$
I A M A
$$

CAMPAIGN BOOSTER ARE YOU?

This Emblem Awarded By 

Examle 5: Hone Canvassor's mamal usod by voluntoer workers lar coly

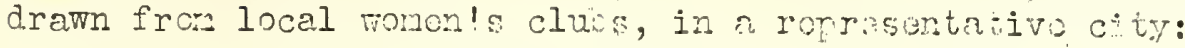

\section{INSTRUCTIOIS FOR CAINVASSERS}

You, as canvasier for the Hodernizin Canpain, rill be asked numerous questions resardin the purposes and the methods of the campaign. Sorne of those questions can lo anticipated. In attempt is made hereby to set down a number of thom with their answers. If these and other pieces of liturature with wich you are supplied do not give you a satisfactory ansmer, take the questioner's namo and address and refor the question in witton form to Camperisn Hoadquarters, ___ or, if you prefor, telephone tho question imrediately to Hendquarters.

Q. Is the modernizin and ropair canvass a fund-raising campaign?

A. No. Nobody is called upon to contribute cash or a pledse of cash. The proporty omer is asked to supply morl by having done imnediately jobs or real cstate improvenent; honce, he mill release purchasing pover so that erployment nay bo furnished, directly, or indiroctly, to persons cuployed in manufacturing, distributing, and selling the goods purchased.

Q. Tho aro sponsoring tho carnonitrn?

A. The Federation of Wirnen's Cluis of

The Mayor's Inemploymont Comrittee, The Arericar Ifroion, The Better Hones Association, The Builders Exchange, and

Q. How is tho cerropin bein financed?

A. The cxponses of malins, printing, stationery, stonopraphic scrvices, and otten items of sirilar nature are bun paid by a fund contributed by civic-inded citizons and comporations. The canvassers receive no pay, but aro giving their sorvices in bohalf of this movonent to put (city) on a selfsipportine rasis.

Q. What cood does the plan do ne?

A. Tor every dollar you put into your property non, you will get back tro or throe times that arount when times got better. You are doing thin's that oucht to be done before they get worse and cost much nore to ix up. If pou exercise your normal buying porer, bryine the things you neod and want, but the purchase of wich you have reea putting of you cal to settine then now at tho most favorale prices which have provailed for a lon time. Besides, an irporovenent in your house, not equiprent etc., sivo you gront personal satisfaction. 
Q. How can such purchases siminlate erployient?

A. When you tix up your house, the workin receive wages, the people who supply the materials recoivo corponsation fron which they in turn can nay meges, and that money is spont in the stores of (nane of city) _... and then districuta throurh various othor chainels, helpinğ many poole to keop thoir jobs. It is only by circulation of roney trat business can हo on.

Q. I wish to have certain improvementa made to my property. Mill the sponsors of this camaign recomend any particular contractor or group of contractors?

1. Tou ray have the worl done in accordance with your own individual needs ant rith a contractor of your o:m choice, or you can have for the asking the cooperation of Carmaign Hearquarters, located at (nwiter and street) - The Heajguarters vill do all that is possitze to get your needs satisfied.

Q. Nill the list of those who arree to have mork done be published?

A. No. Only the tobal anount of the pledsings and the total nuriter of the peoplo ofo siemify their intention to have the worl: done and to use their norral purchasing pover will be published.

Q. Where can I got in touch with worker to do particular jobs that one or two rien can do?

A. Campain Headquarters, (nuler and street), in cooperation with various other civic akencies set up to supply capable personnel will je klad to see that skilled workers do the job. you want done.

Q. Is there any conflict between the property improvenent movewent and the man-a-block, or other carmaign?

A. No. The mar-a-block plan aims to provide erployment of a specific sort to unericloyed men, assiming a man to a desiहrated block, the residents of which agree to pay a srecified sur to the man eack weok in return for his cleanin walks, carryinf out ashes, otc. It is primarily an odd-job novement. The modernizine novement is more general in scope and aims to kive emloyment to the skilled worker as well as to the unsirilled. In addition it tends to contribute toward the beautification of the netropolitan area. 
Exarple 6: Self addrossod check list card loft with lione owner by canvasser tofether with detailed list of sumester improments, for return to carpaikn headquarters. ( 4 by 6 inch card)

(Front)

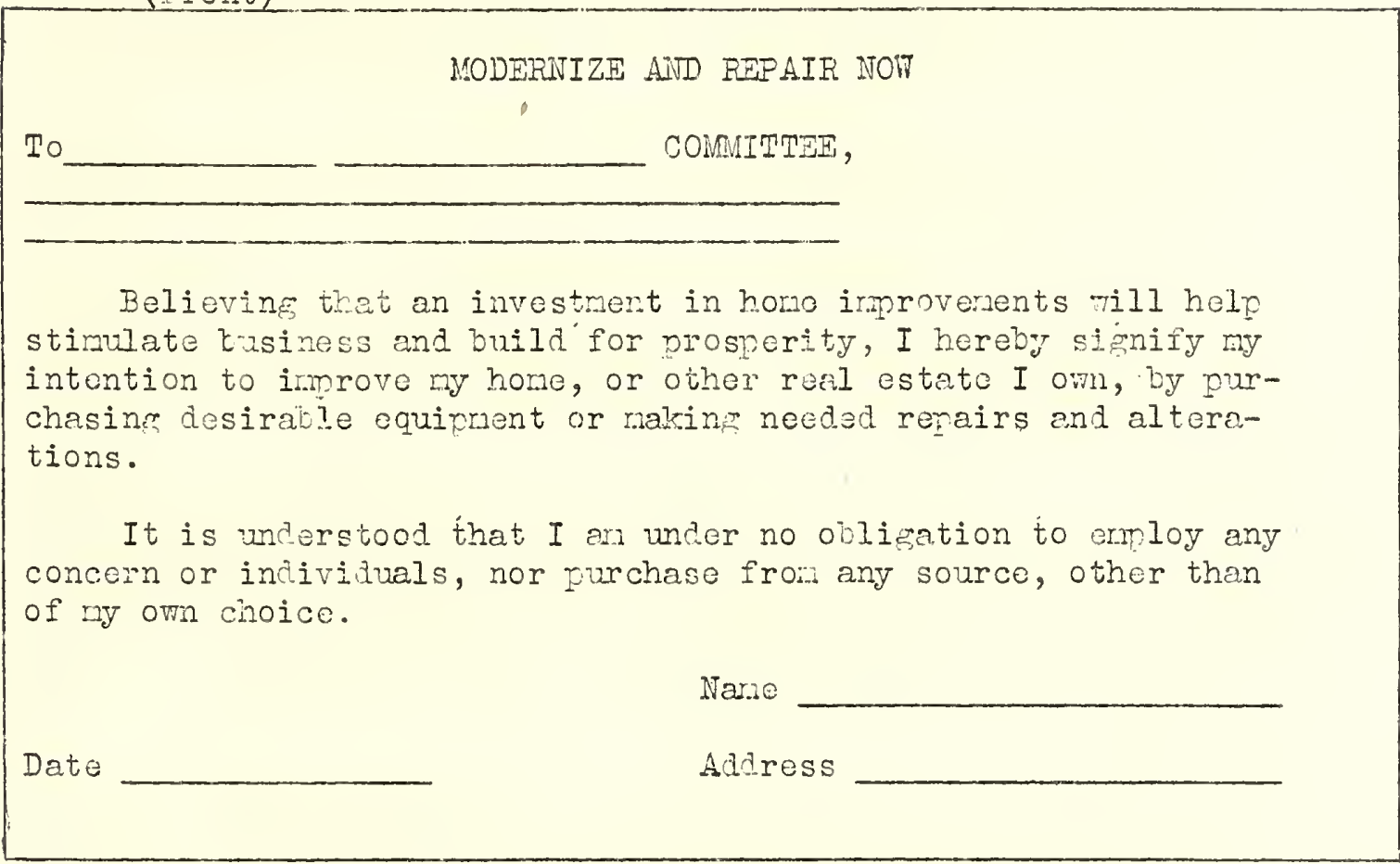

(Eack)

\section{CHECK LIST}

It is my intention to devote to this purpose and I need the followine thin s done:

Dollars $(\$$

Bathroom fixturus Paintins:

Camentry \& cabinets Papering \& decoratine

Electrical work Plasterin

Hardware Plurleins

Hardwood floors Roofing \& sheet metal

Heating Tile worl

Iandscapinf

Masonry and coment 
Example I. Suggested improvements and repairs listed in inexpensive folder vsed by local modemizing committee for distribution to property owners within the commity concernea. (ITote: The 1923-193? connarative prices, of course, apply to one locality only. They would have to be changed to conform with prices in any other commuity where such a list is used.)

\section{DEAR FELIOTI CITIZEN:}

\section{READ THIS FOIDER CARERUIIY}

Read these figures and see how much your dollar will buy to-day, compared to $19 ? 8$.

Mill Work

Lumber -

(Fomlocis)

Brick -

(Common)

(Face, ordinar-

ily used)

Indiana Limestone

Plastering -

Plumbing - (Fixtures)

i.e., bathtubs, etc. $\$ 75.00$

Painting-Exterior

(Average 6 room home)

Interior

$\$ 150.00$

$\$ 16.00$ per $M$

$\$ 25.00$ to $\$ 40.00$

$\$ 3.50 \mathrm{cu}$. ft.

$\$ 1.00$ per yd.
1932

$\$ 19.00$ to $\$ 22.00 \mathrm{M}$

$\$ 40.00$ to $\$ 45.00 \mathrm{M}$

19.

\subsection{0 per $M$}

$\$ 16.00$ to $\$ 25.00$

$\$ 1.80 \mathrm{cu}$. ft.

$50 \phi$ yard

$\$ 32.00$

$50-60 \%$

$\$ 75.00$

$50 \%$

$40 \%$

Electrical Work -

Glass -

Cement -

Interior Decorating -

Floor Covering -

drapes-curtains -

Rugs - all types

Furniture
Savings

$50 \%$

$35-40 \%$

$42 \%$
$40 \%$

$50 \%$

$50 \%$
$35-40 \%$

$30-40 \%$

$\$ 2.00$ a bbl.

$35 \%$ 
CHECK IIST OF SUGGEST ID IMPPOV ENENTS

OUTSIDE

1. REPAIR THE ROOF. REPAINT CANTAS OR TIN ROOFS. Nothing can have more serious consequences than a leaky roof. Reshingle or reslate the roof.

2. REPAIF THE CHIMIII. Point un joints. rebuila top of chimney if necessury.

3. IMPPOV DRAFT OF CEIMATY. Clean flues. Raise height of chimney. Add chimney pots or a sheet met:? ventilator. Repair smoke-pipe connections to flues. Cleen out soot or ashes from the cottom of chimney. Install ash-pit door if there is none.

4. REPAIR, FINEW, OR ADD TO GUTERS AND CONDUCMORS. Leaky gutters and conductors, or gutters that are stopped up with leaves so that the overflow, make unsichtly stains on light-painted walls and are likely to cause a wet cellar. Add more conductors if necessary.

5. DO AII EXTRIOR MINOE EEPAIRS. This applies to cornices, water tables, blinds, porches, floors, steps, and so forth. If these are kept in repair each year the cost will. be little, but if.neglected they soon mount up to an appreciable repair bill.

6. INSTAII STORM MINDOTS, storm doors, or a storm vestibule for exposed conditions. Hang these on special hooks at top so they will be easily removable.

7. REPAIR AND RIPAINT SCREENS or order new ones for spring.

8. SCREMT THE PORCE with removable screens.

9. SCREEN A FIAT, FOOF on the second floor for use as a sleeping porch. If the roof is of metal or tar snd gravel, lay a wood floor to walk on.

10. PUT AMINGS OH SPECIII NINDONS, over a terrace or a second floor flat roof. Order now for delivery next spring.

11. TEATHESTRIP AII OUTSIDE FOORS and windors, at least on the exposed side of house.

12. ADD NET BIINDS to windows having none where these might improve the appearance of the house.

13. REPAIR BUIKE EAD. See thet cover. is strong and tight and that the steps are in good condition.

14. BUIID DRIVETIY OR WAIKS or repoir old ones.

15. BUIID $\Lambda$ SHEITER OVIR TEM FRONT DOOR to give protection from rain. 
16. BUID A COYRID TIY THE GRAGE.

17. RPAIF FINCES or build new onos.

18. MAKE STORAGU SFAC for gerden furniture, screens," storm windows, a baby carriage, sleds, bicycles; grat tools and so forth, in the cellar.

19. Build a garage or remodél a present onê.

20. Repair clapboard or sidire.

21. Build a.play house.

22. Point walls and masoniry.

23. Repair present walls。

24. Put cement floór in garage.

425. Lodernize exterior of house by apolying shingles, brick facing or stricco over present exterior.

26. Add new porch or enclose existing porch.

27. Erect new gates, arbors, pergolns, trellises, bird house, dog house, window boxes.

\section{INSID}

1. Make cellar dry. A damp cellar is bad for a house as well as for its occupants.

2. Repair or lay new concrete floor in cellar.

3. Firestop in the cellar over sills and girders and around pipe openings, and plaster ceiling over heater with hard plaster for fire protection. Provide at least one fire extinguisher above the basement.

4. Insulate underside of "refters' to moke the attic. warmer in winter and cooler in sumer.

5. Install a disappearing stairway in place of a trapdoor to reach storage space in the attic or over the garage.

6. Finish off room in attic or cellar for pleyroom. Malls can be covered with wallboard or insulating board with wood battens to cover the joints. 
7. Cut dormer or skylight in roof to give more light and air in the attic.

8. Lay a new floor, Iay a waterproof floor in a vestibuile, bath, or kitchen or a hardwood in place of a softwood floor.

9. Improve the kitchen arrangement or equipment. If the kitchen is large, concentrute cooking equipment at end near pantry or diningroom and develop the rest of the room with table and seats into a maid's sitting area or place for children to eat.

(a) Iay a new lineleum or rubber floor.

(b) Install a second arinboard besije the sink if there is only one.

(c) Build new storage or:cooking cupboards to the ceiling with contimous counters.

(d) Buy a new stove.

(e) Buy a new electric or gas refrigerator and put it in the kitchen for convenience.

(f) Instali a garbage incinerator in kitchen or cellar.

(g) Build a folding ironing board.

(h) Paint the woodword and walls a light, clean, cheerful color.

(i) Arrange plenty of light outlets, one for general Iighting and one over the sink.

(j) Build in a new sink and mixing faucet with or without an electric dishwasher.

"k) Install a marble slab for pastry making.

(1) Build a screened cupboard for cooling foods.

(m) Build a cold cupboard ventilated to the out-of-doors for keeping vegetables.

(n) Build a rack for platters and trays and a larger one for table leaves in the pantry.or in a closet.

(o) Euy new pots, pans, kettles, towels, broons, mops, pails, etc.

10. Build or alter closets, shelves, or cupboards for the following uses:

(a) Build a long wardrobe closet at the end of a bedroom, divided into separate compartments for riding, evening and everyday clothes. When the doors are shut they will give the effect of a. wood-paneled end to the room. 
(b) Build a man's dressing case into the orner's closet, with spesial places for shirts, ties, socks and so forth.

(c) Iine at least one eloset with cedar on walls, ceiling, floor and back of door, and weatherstrip the door tormake it mothresisting.

(d) Build extroclotwin clnsets as neered. If these are built with wood wils to look like built-in "Tardrobes, they can be easily put into any bedrocm or a hall.

(e) Eit up existine closets with such things as an umbrelja rack for damp unbrollas, shelves for shes or movors, clothes poles (including clothes poles of proper height in children's closets), hat shelvis, linen shelves, china-closet shelves, telephone closet shelf, and so forth.

(f) Plan a speciel storage place, easily accessible, for old boxes, string and wrayping paper, and one for bags and suitcases, sewing machine, and so forth.

(8) Install a cupboard for clean towels and supplies in each bathroom, as vell as a medicine cabinet.

(h) Equip a broom closet on each floor with special broom hooks and shallow sheitres for clearing supplies.

(i) Build a preserve ord vegeteble closet in the cellar or in an unheated back entr. This should be vontilated.

(j) Build in new book ceses where desired, with or vithout cupboards bolon for magizines and games, a wood cupboard near the fireplace, a radio cupboard where the radio vill be out of sight when not in use, a cupbosrd for filing away card tables between vertical partitions, or a special aupbard for large books or rortfolios.

(k) Build a toy cupboard in the playrom to make tidiness possible.

11. Install a clothes chute: This can be done where a second floor closet comes over one on the first floor.

12. Install a folding ironing board in a bithroom or sewing room for upstoirs pressing.

13. Install a built-in packege recejver for delivery of milk or packages when no one is at hand to open the door.

14. Fuild in a smell safe.

15. Install a full-length mirror on one or more doors in a bedroom, bathroom, or sewing room. 
16. Replace soue old glass vith class giving ultra-tiolet reys in a sun-room or children's flayroom.

17. Build a work bench in the cellar or in the garage.

18. Look over all windows and conrs and malie them work properly.

19. Combine tro roorns into one, changing or removing partitions.

20. Provide extra bedroom by subcividing large room, by using waste space or by extra addition.

21. Instell door bed in sering mom, library or extro room (having a closet) to malse a convertibla bearoom.

22. Build a brearfast noo? in unused part of kitches or pentry or buila new broakfast porch.

23. Install hundroils on stairs, (collor, attic, sorvice or main) and recorstruct stairs or coreatest safety.

24. Fepeir crackod, loose or follen plaster on wolls or coiling.

25. Plaster basenent cuiling or metal lath for fir vrotection and cloanliness.

26. Install pine, onk or othor panoled walls in dining or living rooms.

27. Modernize obsolete trim and doors.

28. Install tile flocrs and waljs in bathrom and witchen.

29. Make suitable provision for fuel supply near living or dining room fireplaces.

30. Repair on replace hardyore, sagging; or falty doors and windows.

37. Add extraidoors and windons.

32. Construct new shelves, bookases.

33. Repair worn out or creaking stairs.

34. Fix warped or sagged joints.

35. Fix moodwork and floors.

:36.. Findaresser arawers.

37. Fuild coal and ash bins in cellar. 


\section{PIUNBING}

1. Install new bathroom. Change present bathroom fixtures.

2. Tile present bathroom.

3. Install washtubs in bessment.

4. Fix leaky pipes and water teps.

5. Install first floor lavitory.

6. Install wash-basin. in bodrom,

7. Convert large clnset into extra toilet or shower room.

8. Replace any old plumbing fixture that is shabby or worn out. Consult your plumber about which neir one rill best fit the old situation.

9. Install a pantry sink for washing dishes.

10. Install an extra lavatory in one or more bedrooms.

11. A cellar toilet is often veluable for the use of a maid or those not living in the house.

12. Instali a shower fittire and curtain in connection with an existing bath tub.

13. Install a separate shower stall. This can be a tiled compartment or a ready-made metel shower.

14." Replace old worn-out faucets and fittings with new ones.

15. Replace old toilet seats with new ones.

16. Chromium-plate old nickel-plated faucets and fittings which are unsight ly.

17. See that there are plenty of towel rods in the bath room.

18. Install a new, automatic hot-water heater, using gas, oil or electricity for fuel.

19. Install a water softener.

20. Install aditinnal sill cocks for vatering garden or lawn or for washing the autombile. 
1. Buy new or ropajr faulty eloctric motors, railo, refrigcrator, stoves, heaters, vacuum cleaners, irons, lamps ewl cords, toasters, and other electric appliances.

2. Buy new electric refrigerator, stove, vacum cleaner, dishwasher, heaters, or otino s.cetric appliances.

3. Erect radio aerial and Iimhtning arrestor. Place adaitional viring in house.

4. Install lights in grage.

5. Fix or instill electric door bells and buzzers.

6. Install remote control for radio receiver, built-in speskors, etc.

7. Install will switches at entrences to eliminate pull coris.

8. Modernize lighting system, relocate fixtures, substitute mall brackets for chandeliers, provide new fixtures.

9. Provide low voltage current in playmoons for oporating electrical toys.

10. Install extre electric outlets. A clever electricion can sneke wires through unbelicvablo places to provide all the outlets wanted at reasonahle expense. Every bed should have: a light high enough and conveniently enowh placod to allow reading in bed. Jights in closets, switches on lights which have none, vacuum cleaner outlets in halls, specinl lighting over cookcases, pilot lights on switches to lights that are opt to be left burning by mistake - theso and many others are often forgotten when a house is built.

11. Add a light outside the front door or the garage and one at the gate.

12. Replace old electric fixtures with new, and perhaps relocate some of these.

13. Install modern improvements for the radio. Aerial and ground can be concealed in the wls, the radio can be controlled from different locations in severil aifferent combinations to eliminate an extra piece of fumiture. The radio set mav be placed in a cupboard under book shelves with door opened when it is in uise.

14. Install conduit in the walls for telephone axtensions above the first floor. This does aray with the ungiohtiness of a telephone wire carricd on the outside of the wall in finjshed parts of the horise. 
15. Replace battorios with a small transformer for bolls or house toluphones wer the current is ouicable.

16. Instell an eloctric vertilator in the kitehen. This cen be placod in tho upper sash of a rindom, or better, in an outside wail.

17. Install an electric plate warmer in the pantry.

18. Install a buit-in lectric bathronm heater. There is often need of extra noat in the bath room.

19. Add new liwnary equipment, wuch as washing nachine, mechanical ironer, nr a cloches drier for drying the clothes by artificial heat on rainy davs.

20. Have electric wing checked up for safety to accord with roquiremonts" of National"Bowd of Eire Urderwriteis and of your insurance corpany.

\section{PAINIING}

1. Paint the outside of the house.

2. Pxterior woodloors and door throwolds shoula bo oiled frequently.

3. Witevash tho ebliar and paint cellar partitions white. The cellar is light arid oasior to kep neat and clesn if it is white, or a ligigt color.

4. Paint the inside of the garnge to encourago noatness and cloanliness.

5. Calcimine the ceiling in a rom which is to be rodecorated, or paint the coiling in tho kitchon $n$ a bathroom whore steam would affect calcimino. Patch culing crecks before calcinining, or covor a bialy crocked ceiling trithoslin ana paint. If cracks are too bad or plaster around then is lonse, a plasterer will have to be called in to do tre patchire.

6. Paint or refinish the woodwork in a rocm which is to be reảecorated." If varnished or darli-colored wodmorz: in a kitchen or lawndry is painted a light, neutril onlor, it will give an active feeling of cheerfulness to onewherks in these rooms. Color interest can be acquired by pairting the glass divisions in windows or elazed cupbocira in a cortrestiar colnx. 
7. Paint the wals of zitchen, lowary, hath or ay rthor room desired. Ir the mlls havo beon mintel befor nid the colno is to renain aproximetely the seme, one coat will be sufficiert. If the color is changel, tio coats mill be necessamy, and neir mals will. renire at lenst thres coats bosides a coat of sizing.

8. Redecorate the valls with wilnapor, plastic naint, calcimine, or a washablo mall corering.

9. Fefinish the floors. Floors should be kept up by having thom talien care of irequently. At wch times they sinould be thoroughly washed with soap and warm water. Worn waces shovla be touched up with stin or peint as nesded, and then the floors shovld be given a coat of sleeliac, vornish, floor polish, oil, wax or floor paint, as the case may be. A concrete rloor can be fiven a coat of chemicel floor rardener to lay the dust, or cen be painted nur dasirea color th special point made for the purpose.

10. Paint radiators, wereraly with non-metalic paint.

11. Paint base receptacle plates and switch riates to match the color of the moodworle or wall against wich they are placed. Paint lighting fixtures to match ralls or in an accent color to suit the scheme of the room. Old ternished rixtures can be made to lonk like new.

12. Paint handes of sarden tools, wheelbarrow and lawn rower.

13. Paint fences and lattices.

14. Paint giarage.

15. Repaint woodwort, floors, booiccases and sholves.

16. Fewax flnors and. modrotz.

17. Polish all Purmiture.

\section{EEATING}

1. Install a ner boiler or furnace. One of the norest desinns my save enough fucl to rey for itself in a fer years.

2. Add forced circulation to ar old werr-ajr systom, by inst: llin cold-air roturn resistars from vaious points in the house, by installing a fon to force air throunh the tholo sistem, or by installing a fon in a single pipo to corract slugessinoss in a special pipe to a room thot is hard to heut. 
3. Replace old velves on a aterm ststem by more rodurn, efficicnt ones.

4. Install a themostat to control your henting systom cutomatically. This can bo done with any trpe of fucl. With a clock themostat the heat $c a n$ be shut dorn ni night, if desiravle, and will automaticllir cone up to give $a$ higher temperature at a predetermined time in the monning.

5. Attach an indirect heater to a stean boiler to heat the hot water for the pluming systom while the heatei is in operation.

6. Install concealed raciators in important rooms in place of freestanding ones here these are objectjonate in appearance. These can be either in cabinet form or rult into the valls with erilles in front.

7. Heat the garage. If the earace is built into the house, or is near enourin to it, it can be neated from the house boiler, provide? the hoiler is Lerge enoukh to taike the extra load. Otherwise a seprate heater will have to be installed in comnection with the sarage.

8. Cover a boiler or heating pipes in the cellar with some good pipe covering to couserve heat and to rawe the cellar cooler.

9. Check boiler and hot-woter heating sistem for all necessary safety appliances.

10. Correct hoating of cold room by.-

(1) Weatnorstripping, or

(2) Insulate side whls and ceiling, or have fibrous insulation blown into dead spaces.

11. Increase size of existing radiators.

12. Install axiliary built-in electric or gas heaters.

13. Relocate or replace radiators in one or more rooms.

14. Install additionol radiators.

15. Install gas or electric log in fireplace. 


\section{IAINDSCAPE TORI}

1. Arrange an outdoor living space, a terrace with comfortable vaterp=oof furniture, to encouriage a maximum of outdoor living in the sun.

2. Arrange a place to eat breakfast out of doors in the sun.

3. Arrange a play space for the chilaren where they have a sand kox and a swing or two, well separated from the rest of the grounds.

4. Arrange a laundry drying yard which shall have morning sur if possible.

5. Plant a large tree for shade over the terrace or elsevinere. The cost of a good-sized treo is not prohibitive.

6. Plant a hedge along the street boundary or to divide separate areas in the sround plan.

7. Plont a garden or at least a flower bed.

8. Pmine trees and shrubs, remove dead wood, and keep existing trees repaired.

9. Install a water line from the house to one or more hose outlets in the garden.

10. Fill or drain stagnant spots in the grounds to prevent mosquitoes.

\section{MISC ELLANEOUS}

Upholster - Davenport, chairs, lounges.

Clean - Draocries, ngs and upholstered furniture.

Wash windows, woodwork, etc. 
Example 8. Deinonstration undernized home contest cniducted during home improvement cumpaign a a tricul southem cit contest was particulnul" interesting as a "before" and "after" example, in that two practicaliy iacntical hruses, locatca close to each other, were used, one of whicil was indemizod throu shout, under architectural supervision, and the other was left in its original condition during the inspection period.)

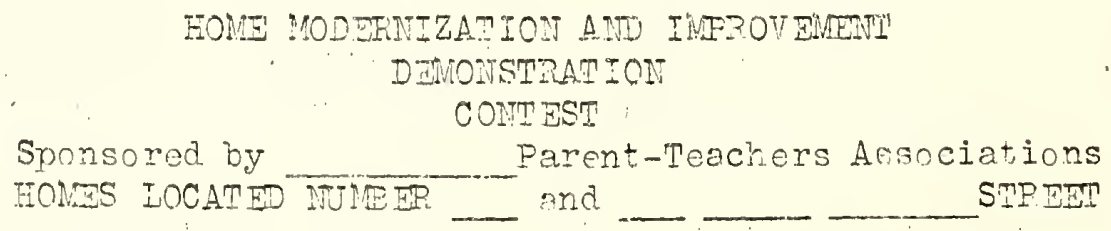

With the approval of the P.I.A. Couricilall individual associations will particinate in a contest to secur? the largest number of risitors to the hodernized fome demnstration conducted by the Home Kocornization and Improvement Committee of the Chamber of Commerce.

Rules of Contest:

No. 1. The cnntest will be to determine which Parent-Teachers Association can get the largest number of neonle to inspect the Modorniaed Home. Registronts need not be members of a Paront-Toachers Association. The whole idoe is $\mathrm{r}_{\mathrm{r}}$ each Association to get as many people out to see the Demoustration Fome as yossibie.

The Associations registering the largest nunbor wndm the mes will raceive the following prizes: First prize $\mathrm{w}^{2}, 00$ : Second prize $\$ 20.00$, Thine prize $\$ 15.00$, kourth prize $\$ 10.00$, and the rifth prize $\$ 5.00$.

No. 2. The contest will begin Monday moming, Soptember 7 th, and will continue each day through september lith.

No. 3. The houses will be open for pulic inspection each day during the above week at the following hours: 11:00 A.M. until. 2:00 P.M. and $5: 00$ until 10:00 P.M.

No. 4. Prizes will be awarded on attendance secured by each individual association on a percentage basis, i.e., the total onrollnent in each school and the number of children over io years of ace in each school.

ITo. 5. Parents who registor will count for each suhol in which they have children provided they put a check on the cara beside each schon]. in wish thoy have childron.

No. 6. All school children 10 years of age and nver who visit the homes will count one point in the contest. 
No. 7. All achlts regardless of rilether or not they are members of the P. I. A. nav be invited to inspect the homes and Adult registration will count two pirts for the Assciation created with such registration.

No. 8. The presjaent of each asscoiation will be supplied with registration cards for nembers to distrihute and may securo adcitional cards by calling Mr. at the Charber of Commerce - phone

Suggestions to Presidents and Workers:

Contact with all merabers of Jour Association and find out exactiy how many you can count on to work in tho contest. Get all of your om association memers to register before sne other association registers them. Assign each worker a certain muoer n people to invito visitors to inspect the Mdernized Hones and register. About the midale of the week contact with all woricers and nake sure that they have registered their quota; if thoy havo, assism thon an aditional quota. It is not necessury that the worizer bo prosent when visitors register in the name of that worker's assciation. Got the penple to gn by at lunch time - on the way hrme from rorm or after the show at night. Contact with the people by telephone and esk them to reenistcr for your Asscia-

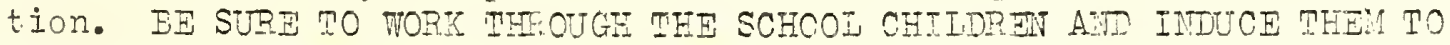
GET THFIR PAPENTS, BEOTHPRS, SISTTRS, AnA FRI INTS TO REGISTIR FOR YOUR ASSOCIATION.

The results will be checred by a certifiod public accountant and prizes will be avardea on the basis of his report.

Example 9. Radio addrese dejivered in conection itin a Incal aspressive home improvement promam. (Note: Other similar talks are availab.le from the Committee on Reconditioning, Rernoleljng, and Modernizing.)

\section{DIVIDEMS FROH MODIENTZING YOUR HONE}

Radio adjress delivered in connectinn with local modernizing campaign over station Mrnday evening, March 21, 1932, at 7:45 P. M.

God evoning, ladies and entlemen - It is with considerable pleasure that the Philadelphia Peaeration of the Constmetion Incustry and the Philadelphia Chamber of Crmerce besin this series of radio broadcasts for the purpose of quickening the interest of home owners who still have a dollar or two to spend in improving and modernizing their homes. I am certair that you will find this series of broadcasts entertaining and different - different in the sensc that each radio adaross mill have in it something of material benefit to you desicmed tr add to your comfort and to savo 
you money. During the past two years rou have been appealed to in behalf of meny interests other then you own, and invariably you have responded sympathetically am generously. Fut this appeal is entirely different. Now you are being sked to do something for yourselves and to do it with the prinary purnose of benefiting yourselves. The object of this arreal is to set you to take a greater interest in your outstanding investment, that is, your home.

Neither this radio talk nor the subsequent broadcasts in this series are seeking to persuade you to draw dom jour savings account against your better judgment. Despite tinis last unwelcome touch of winter, spring is just around the corner, and the example set at this time by nature getting reacy to adorn herself in her net garb of blossoming trees and velvety greenswarc is one which can be profitably followed by the home owner in redecorating and restoring his home. Not in a decade have you inad the opportunity to add so mach to the convenience, the comfort, the appearance of your home at such low cost. For more than two years the American people have been putting off practically everything in the nature of home impovements. In a desperate effort to keep oisiness at reasonable volume, business enterprises "handing materials which entor into home improvements to-day are quoting lower and still lower prices. This situation has made an opportunity for the home owner. which will not lasc mach Ionger.

So when the opnortunity is ripe, seize it. Make an inspection trip through your home and list the things to be fixed or renewea. Check carefully with me the following list of itens. But dor't be like the lazy mar with the lea? roof who always drawlea tinat his roof didn't need fixing whon the sun was shining, and who was always too fearful of a drenchins to repair the leais wen it was raining. For example, repair your porch columns; redecorate vour rooms; repair leaking roofs; beautify your floors with linoloum or hardwood surfacing; refinish the sorely neglected chimney or fireplace throat; renew or repair your sidewalks; make your creakino or rickety stairs neat and noiseless; paint or refinish your wookwork; fix your doors and windows; repair. vater taps that drip, mated gutters or domspouts; remodel your funiture. Or, if the money is available for a slightly larker job, build the new sun porch that you have long wishea for, erect the garage or remodel the front facade of your house.

There are many aspects to this progrem which makes it worthy of your serious consideration and imediste action. In the first place, the cost of the materials involved are the lowest that they have been for fifteen years, and with the declines in wages which have occurred in the past two years, the labor costs are today 25 to 50 per cent cheaper than they have been for d decade ox.more. This means that today your average costs incumed in making the necessary repairs or improvements to your home will be from 50 to 100 per cent cheaper than they have been at any time since 1920, and, if our business forecasters are to be believed, mch cheaper than thay will be in the next Iive or ten years to come. 
In the second place, resorting to your savings account or even borroting to-day, if your job and salam are reasonably well assured, will create a tremencous anount of emploment for men in the building industry and allied fields of craft manchip, ani thus give a decided stimulus to business at larse. Wren one considers that about 75 per cent or moie of the dollar spent in molornizing the home soes to labor instead of materials, the tramendous ilmoutance of this home modemization plan in helping unemployment is the Philadelphia area immeilately becomes clear. Moreover, repairirg ancimproving and redecorating your home at a time like this will tend to increasc the business of those concerns which supply matorials for this work. And when you recollect that Philadelphia is classed as the world's worlzshop throughout the commercially civilized. world, again the vital meaning of a home modernization program to the industries in this community js avident. In this comection, this js not a now and untried. idea. Cities lize Mncie, Indiana; Pockester, Jen Yonls; Greensboro, North Carolina; Springfield, Ohjo; Shreveport, Louisiana; Portlond, oregon, and many others are shining iljustrations in point. The experience in each of these cities demonstrites that no sounder program to create mployment has ever been offerea. Everyone benofits. Retail trade is brisker. Food and clothing are more in demand. Need for relief work is diminjshei. Sums of moner collected for charity are less.

In the thind plsce, imporing and moderniptas your home as previously suggested will resuli, not only in beantifying the gereral appearance of your neichoorhood, but more juportart to you as s home owner, you will increase enomously the value of your home as a business proposition. It has been estimated that a mur-kown property that can be bought now for $\$ 3,000$ will be rorth $\$ 6,000$ eventueli is $\$ 1,000$ is put in to ranodel ard nodomize it to-day. Honey talren ran the savings account provided jt can be spared, or evom molor boryoved where your circumstances definitely assuro you of rpaying it, will go into the soundost investment you can possibl mare at this tine, if with it you modernize and improve your nome. Iiston to the VicePresident of the Imigrant Industrial Savings Rank of New York City when he says "Keep o: deposit all rol shovld have as a resarve against emerencies. If you have a suplus aove all likely need, maire careful purchases of things you want for permanent use while prices remain low. See that jour home is put in good repair." So, following this advice if $y 0 u$ invest an in juproving, mokernizing, ropairing and reconstructing your home you vill save monoy for ynursalf. as c proptrty orrer.

And incidentally, you will be adding substantial surn to the value of rour property as a piece of real estate. Yow will increase in every way the possibilities of placing a mortgere against our pronerty, or if one already exists, of increasing it. You will make yon home much more desirable collateral for a loan at the bank. You will strenethen the nation's finanoial stucture through the beneicial irfixence which your home improvements will have on realty values. 
This plea for mojernization and inprovement is basically designed to bonefit your pocketbonk.: It is a plea enthusiastically suppnrtë by bankers, economists and indistrian. Inaders throumout the United States who are unanimous in exoressing thoty opininn that now is the time to repair and to improve.: Certainly, ynu, like every other home owner, have at some time pictured to jourself the changes or additions which if made to jour home word la give it that added touch of comfort and bearty which means so mich to the restfulness and contentment that a home can afford. Consequont $1 y$, when you are listening to subsequent speeches in this series of broadcasts, leep you.r ear alert to catch the suggestions made first hand by dej.ers and expert bujlding creftsmen concerning materials and methods to be used in bringing your home up to date.

In other words, it is not simply a question of making necessary repairs, but of improving your home. By the wise expenditure of a few dollars now you can secure the benefits of söne modern device developed in the past ten years that will add a thousandfold of comiort and convenience to your home. For example; the new system of insulating buildings by means ol fikirous or feit materials will save from 20 to 40 per cent on your winter. fue? bills, an at the same time this insulation will make tire interiom. of your hom ten deerees cooler in sumer. It is perfectly poseble to apply insulation of this type to homes already cuilt, for scversl leading manufacturers have porfected a blowing process by which loose-fill insulating matertal is forced into the walls between sheathing and plester lath. compesseả air. Similarly, anyone of the modem tynes of floor covaring, whethor asbostos or rubber tiles, or the netor desions in oilcioth or linoleum may well be used to convert what once was a tawdry room into a room of charm and artistry. Again, ceramic tilos are a most versatile builaing matorial. With corarnic tile your vitchon con be made one of the most attractive rooms in the house, and the boartiful spotless floors of Dutch, Flenish, French and Old English dining rooms pive ne countless exmles of the appropriateness and beaty of cemic tiles for dining roor, breakfost room or entrance hall. Iivowise, the modem hoating systems to-day are designed to supply moisture to the ir in your home for the benofit of your hoalth and comiont. Improv ments.in this lino have almost completely transfomed the warmi-air lrenting system that was in vogue ten years ago, not only in the quantity of heat but in its complote diffusion trroughout the room.

So before coning to the important announcement, let ne sumarize briefly why you should begin to repair, improve and modernize your home to-day - right now. It can be done a.t lowest cost. You will find the workmen are more efficiont because they have ample time to do the job right. Yor can make of your home a riace where the nicer refinerients of this modern age remove all of the potty inconvenionces and at the same time add significant touches of artistry and comfort to your daily life. You will improve your home as an investment, increase realty values, decrease unemployment and stimlate business goner lly - in a word for every dollar you spend to-day on home improvements wor vill set in motion a series of faworable forces in business that will all come back to you in the next two or three years in douhle - yes, triple dividends. 
And, here is the announcoment you inve boon waiting for. To prove the good faith of the buildirg and raterial intérosts in Pliladelphia in this home modernization and improvement progren, und as evidence of their willingness to contribute their bit to arouse your intorest in this plan, there will be offored each week fifty dollars in prizes for the bost es-" says showing how improvements in neating, plumbing, ventilátiou, roofing, painting, decorating and so forth woud modomize the home, and why these improverionts should be made now. The first prize offer will be made at this same time next reek. The hone ownel in Philadelphid or its suburos submitting the best essaj will receive a fifty dollar prize in the form of a work order ontiting him to have that arount of work done to his home by accredited craftsmen in the buildin industry. So listen in next Monday evening to hear a speaker discuss the topic MODERINIZE YOUR HEATING, PLIMBING AND VENIIIATION. After you hear his radio tali, thon preparo jour essaj in accordance with the details winich will be announced and. send it in for a prize.

Example 10. Sample news release on modernizing activities, Dopartment of Commerco Pross staff to nowspapers and trado magazines.

\section{HOME IMPROTHUENT CANE AIGNS SEEN AS GOOD COMNUNITY INVESTIRENT.}

That an or sanizod bone-improverent carpaign is a worth-while community investrent is revealed in a study of the costs of such carpainns conducted in twenty cities througiout the country. These cities mere selected as typical from a list of cighty--two which have reported results of campaing to the Comierce Dopartmont's Fome Modernizing Comittec.

Tho population of tho cities studied rarged from 10,000 to 300,000 with carpaign costs varving from $\$ 100$ to $\$ 5,000$. Actual plodges toward property improvesents obtained as a result of the carpaims varied from $\$ 40,000$ to more than $\$ 10,000,000$.

The average population of the twenty cities was 74,000; the average per capita expenditure on the carpaigns less than two conts, with an average per capita investuent in property imorovoments around \$14.00.

While each citizen of a comanity conductine a modernizing caripaign naturally does not either contribute to its expense or benefit directly by its results, it is pointed out that no city can spond amounts ranging, from $\$ 40,000$ to $\$ 10,000,000$ locally without stimulating local businoss and improving the local labor situation.

The cichty-two cities which conducted modernizing camaigns in 1932 and reported to the home-nodernizing comittec have obtained pledjes for property irmprovements aşregating $\$ 56,000,000$. About 70 other cities conducted carpaigrs, but did not report araunts spent.

The Comittee on Reconditioning, Rerodeline, and Modernizinf, Division of Building and Housinf, of the Bureau of Standards, Defartment of Comerce, will be glad to furnish detailed information on methods of conducting home-iuproverent carpainns. 
Example 11. Report showing business and employment which resulted from local home imnovement campaigns in 1932.

Summary of Estimated Ixvencitures for Labor and Materials

Reported by Iocel Modernizing Compajen Cormittees

Irom Jan. 1,1932 , to Dec. 31,1932 .

(Prepared by advisory committee on ieconditioning, renodeling, and modernizing, Division of Building and Fousjing, 'Bureau of Standards.)

\begin{tabular}{|c|c|c|c|c|c|c|c|}
\hline State & and City & Population & Anount & State & and City & Poprilation & Amount \\
\hline Ala. & Birmingham & 259,678 & $\$ 1,000,000$ & N.J. & Trerton & 123,356 & 200,000 \\
\hline Ariz. & Phoenix & 48,118 & 157,678 & N.Y. & Buffalo & 573,076 & $2,000,000$ \\
\hline ark. & Little Rock & 81,679 & $2,680,000$ & $"$ & Clinton & 1,475 & 20,150 \\
\hline al. & Riverside & 29,696 & 120,955 & $"$ & Funtington & 25,582 & 351,000 \\
\hline$"$ & Sacramento & 93,750 & $2,29,4,371$. & $"$ & Kingston & 28,088 & 300,000 \\
\hline$"$ & San Jose & 57,651 & 50,000 & $"$ & Kips Bay* & &, 000 \\
\hline Conn. & Fairfield & 17,218 & 90,0 & $"$ & Foughkeepsie & 40,288 &, 977 \\
\hline$"$ & Meriden & 38,481 & 600,0 & $" 1$ & Rochester & 328,132 & $6,000,000$ \\
\hline Fla. & Lakeland & $.78,554$ & 15,000 & $"$ & Saranac Iake & 8,020 & 75,000 \\
\hline Ill. & Danville & 36,76 & 300 & $"$ & Tarrytown & 6,841 &, 000 \\
\hline$"$ & Evanston & 63,3 & 500 & $"$ & $\mathrm{ca}$ & 101,740 & 1. $, 738,000$ \\
\hline$"$ & Freeport & 22,0 & 500 & $\mathrm{~N} . \mathrm{C}$. & eville & 50,193 & 267,000 \\
\hline " & Galesburg & 28,830 & 1,005 & $"$ & mington & 32,270 & 75,000 \\
\hline$"$ & Streator & 14,723 & 3.2 & Ohiso & 11icothe & 18,340 & 2,622 \\
\hline$"$ & Urbana & 13,060 & 100 & $"$ & Cincinnatj. & 451,160 & $4,500,000$ \\
\hline Ind. & Elkhart & 32,049 & 500 & $"$ & imous & 290,564 & $2,000,000$ \\
\hline & Jasonville & 3,536 & & $"$ & & 200,082 & 100,000 \\
\hline " & Moncie & 46,548 & 333,333 & $"$ & Iton & 52,176 & 43,000 \\
\hline Iowa & Keokak & 15,106 & & $"$ & Narietta & 14,285 & 12,000 \\
\hline an. & Manhattan & 10,1 & 83,896 & " & & 31,084 & 55,000 \\
\hline . & ersboro & 22,7 & 5,000 & 0,12 & McAlester & 11,804 & 70,00 \\
\hline Mass. & Gloucester & 24,204 & 50 & ". & Ponca City & 16,136 & 250,000 \\
\hline$"$ & Holyoke & 56,537 & 12.4, & $"$ & & 141,258 & 100,000 \\
\hline$"$ & Orleans & 500 & 500 & Oro. & Bo & 8,848 & 5,000 \\
\hline$"$ & & 37,355 & 327 & $"$ & Corvallis & 7,585 & 300,000 \\
\hline Mich. & roit & $1,568,662$ & & $"$ & Inand & 301,815 & $10,51 \div 8,13$ \\
\hline 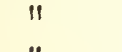 & Jackson & 55,1 & 343 & $"$ & & 26,266 & 300,00 \\
\hline$"$ & & & 40,625 & Ponn. & Carlisle & 12,596 & 104,00 \\
\hline$"$ & Sasinaw & & & $" 1$ & & 25,908 & 471,000 \\
\hline Minn. & Draluth & 101,463 & $3,700,000$ & $"$ & Titusville & 8,055 & 50,00 \\
\hline$"$ & & & 7,387 & s.c. & leston & & 75 \\
\hline ". & St. Cloud & & & Tex. & ston & 202 & 205,00 \\
\hline Viss. & Jackson & 48 & 110,000 & Va. & Richmond. & $1.82,929$ & $2,527,00$ \\
\hline & & & 100 & $"$ & noke & 69,206 & \\
\hline Nebr. & Lincoln & 75,9 & $1,798,248$ & $"$ & Strunton & 11,990 & 4,16 \\
\hline " & Onaha & 214,005 & 500,000 & Tash. & Spokane & 115,514 & $4,099,869$ \\
\hline N.J. & Collingswood & & 66,0 & " & Yakima & $2.2,101$ & 150,00 \\
\hline & Elizabeth & & 400,0 & T. $7 a$ & Clarksburg & & 400,00 \\
\hline$"$ & East Orange & & 2n? & & theeling & 61,659 & 568,81 \\
\hline$"$ & Montclair & 42,017 & 138,00 & Wis. & Oshkosh & 40,108 & 175.650 \\
\hline & Morristown & 15,197 & 62,200 & 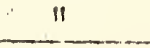 & Siperior & 36,113 & $\frac{000}{570}$ \\
\hline
\end{tabular}

